\title{
FORUM
}

\section{Feminism and contemporary celebrity culture}

Hannah Hamad \& Anthea Taylor

Department of Film Studies, King's College London, UK; Department of Gender and Cultural Studies, The University of Sydney, Australia.

Hannah.hamad@kcl.ac.uk; anthea.taylor@sydney.edu.au

\section{Notes on editors}

Hannah Hamad is lecturer in Film Studies at King's College London, and the author of Postfeminism and paternity in contemporary US film: Framing

fatherhood (London and New York: Routledge, 2013), and numerous articles on postfeminist popular film and television, Hollywood stardom, contemporary celebrity culture, and UK cultures of reality TV.

Anthea Taylor is a lecturer in the Department of Gender and Cultural Studies at the University of Sydney. She is the author of Mediating Australian feminism (2008), Single women in popular culture (2012), and Celebrity and the feminist blockbuster (forthcoming).

In November 2014 TIME magazine nominated 'feminist' in its annually recurring 'word banishment poll,' to identify and denounce the most overused words, phrases, diminutives and acronyms of the year; thereby placing the word that denotes identification with the ongoing global struggle to achieve gender equity in all spheres of human life alongside the likes of 'OMG,' 'obvi' and 'yaaassss' (Steinmetz 2014). This in itself was symptomatic of the extent to which the term, if not the concept of feminism and the values inherent to it, had been a buzzword of 2014 but especially and it is this with which the magazine took particular issue - in spheres of celebrity 
discourse. The injudicious inclusion of this word was unsurprisingly met with instant outcry from commentators across the feminist blogosphere (Little 2014; Merlan 2014) and within mainstream media (O'Connor 2014; Rosenberg 2014); not least because it was winning the poll by a landslide. It quickly produced a public apology from TIME editor Nancy Gibbs, who mitigated her statement by highlighting that 'feminist' was included with the intention of critiquing what was perceived as the glib celebrity appropriation of the term that ostensibly gave rise to its popular cultural prominence in 2014:

You have nothing against feminism itself, but when did it become a thing that every celebrity had to state their position on whether this word applies to them, like some politician declaring a party? Let's stick to the issues and quit throwing this label around like ticker tape at a Susan B. Anthony parade. (Steinmetz 2014)

As indicated via TIME's disapprobation of the phenomenon, the figure of the selfprofessed feminist celebrity was a recurring feature of Anglophone celebrity culture in 2014, snowballing over the course of the year to become a sustained and ongoing flashpoint of the cross-media celebrity landscape. Media culture in 2014 was littered with touchstone moments that saw some of the highest profile female celebrities, as well as many male celebrities, openly identify as feminist. This could be seen in declarations that ranged from those carefully orchestrated to garner high profile publicity, to others that were more responsive to unforeseen events or reactive to what was fast becoming a celebrity zeitgeist. Jennifer Wicke's 1994 remark that 'The energies of the celebrity imaginary are fuelling feminist discourse and political activity as never before' (758) are thus more pertinent than ever. 
Major examples included the contrived iconicity of the performance by pop star Beyoncé at the 2014 MTV Video Music Awards in August. As discussed by Nathalie Weidhase in this issue, Beyoncé appeared on stage with the word 'feminist' illuminated in oversized lettering behind her, after excerpted words from Nigerian novelist Chimamanda Ngozi Adichie's now much reproduced 'We Should All Be Feminists' (2014) speech accompanied her performance. In September, British film actor and celebrity Emma Watson, in her capacity as United Nations Women Goodwill Ambassador, garnered comparable levels of publicity following her delivery of a speech on gender equality to launch the UN's related \#HeForShe Twitter solidarity campaign. On the back of this, as Jessalynn Keller and Jessica Ringrose investigate elsewhere in this issue, she was selected by the UK iteration of fashion magazine ELLE as their 'fresh face of feminism' for 2014. The outspoken response by Hollywood A-lister Jennifer Lawrence to the online publication of her stolen nude photos saw her publicly take up an ostensibly feminist position when, in an interview with Vanity Fair in October (Kashner 2014) she denounced the act as a 'sex crime' (p. 136). While entertainment industry polymath and Girls (HBO, 2011-) star Lena Dunham wore her pro-choice credentials on her sleeve with her pink t-shirt initiative for the non-profit reproductive health organisation 'Planned Parenthood' in support of their 'Women Are Watching' political campaign. Meanwhile, the self-proclaimed feminism of male celebrities like Aziz Ansari has been met with ambivalence by some critics who viewed the public declaration of his feminism in October as typical of the ways in which feminist discourse has been appropriated by postfeminist masculinity. In her contribution to this forum, Shelley Cobb further considers the phenomenon of the 'Male Celebrity Feminist', a figure who poses many questions for feminism and reveals much about the gendering of celebrity and the inequitable 
power relations that structure the field. And in terms of the anxiety yet provoked by the epithet 'feminism,' 2014 also saw celebrities, like Katy Perry, Kelly Clarkson, Lady Gaga, and Shailene Woodley publicly refuse to identify as feminist, and sometimes to conflate feminism with misandry. Intersections of feminism and contemporary celebrity culture are therefore myriad, complicated and contradictory.

Commentary arising from these flashpoints has been abundant, and opinions on the feminist political efficacy of these celebrity self-outings have - unsurprisingly - been divided. Interviews and debate that ensued from these particular cultural moments reveal little or no consensus on feminism among celebrities (what it is, what it should be, what's at stake for celebrities in self-identifying as feminists or not) and some reveal standpoints on feminism more reminiscent of the individualist, apolitical or backlash discourses of millennial postfeminism. Such celebrity voices are crucial to popular understandings of feminism, but not without active making of meaning and contestation from audiences, as Keller and Ringrose demonstrate here.

Writing in The Guardian feminist commentator Roxane Gay (2014) sounded a note of caution lest the potential entry points into feminist thinking offered up by these celebrities be taken for feminism itself. Others, like Annie Lennox (see Weidhase here), similarly argued that the feminism of celebrity women like Beyoncé represents it in a watered down, commercialised form; this is a criticism that has, problematically, long been made of media's engagement with feminism and of individual 'celebrity feminists' in particular. However, when thinking through the complicated nexus of feminism and celebrity it is important not to simply reinscribe familiar critiques that presume this relationship to be inherently negative for feminist politics, and to recognise that there is no 'authentic' feminism that exists beyond its celebrity manifestations (Wicke 1994). Instead, 'feminist star studies' (Projansky 
2014), following Wicke's (1994) earlier exhortation, needs to attend to how feminism and celebrity culture (and media culture more broadly) necessarily intersect in ways that may be at once productive and unproductive, with constraints and possibilities (Taylor 2008). For example, as Weidhase demonstrates here, mainstream celebrity feminism is characterised by a pronounced whiteness, something which has, however, been recently disrupted by figures like Beyoncé. As the pieces in this Forum make clear, what comes to be popularly made available as 'feminism,' including via the realm of celebrity culture, requires further, more nuanced critical thought.

As critics have shown, discursive struggles over the meanings of feminism are now, perhaps more than ever, largely staged in and through media culture; and given that celebrity interventions into on-going debates over feminism have recently intensified, this Forum seeks to come to terms with the ideological and cultural implications of these publicly staged discursive contests. Building on Anthea Taylor's work on 'blockbuster' celebrity feminism (2014), this themed issue of the Celebrity Studies Forum takes the conversation toward the contemporary phenomenon of feminist discourse as it is adopted by major figures in the upper echelons of mainstream celebrity culture. We therefore offer a selection of pieces that interrogate today's celebrity 'feminists' with a view to unpacking what is at stake for celebrity culture and what is at stake for feminism.

Broadly, the case studies proffered illustrate the varied ways in which feminism in the mainstream cultural imaginary can be refracted through celebrity. However, while arguably more pronounced in the past year or so, the phenomenon of 'celebrity feminism' (a term first coined by Wicke) has a much longer, and complicated, mediated history. The particular celebrities analysed in this forum differ from renowned women who have been commonly associated with feminism in 
mainstream media sites - those whose very fame is the product of their feminist enunciative practices, i.e. authors of non-fiction feminist bestsellers who continue to be visible, like Germaine Greer, Gloria Steinem - whose recent appearance on CBS's The Good Wife (2009-) suggests her celebrity capital remains undiminished), or Naomi Wolf; women who are famous because of their feminism and its public performance (see Taylor, forthcoming). There are, then, a number of ways that feminism and celebrity can be seen to explicitly intersect - most obviously through feminists who have been celebritised (as above) and, more recently, through celebrities who come to identify as feminist at some stage during their career, and use their public persona to articulate political positions broadly consistent with feminism. These include some of the figures examined here, as well as women like Tiny Fey, Amy Poehler, and Lena Dunham who arguably straddle both these forms. There are, too, increasing numbers of 'ordinary' or 'micro' celebrities (Senft 2008) who seek to intervene in these debates over the meanings of feminism through various forms of social media, garnering high public visibility, and illustrating that the yoking of celebrity and feminism continues to evolve. Though markedly different, these modes of feminist celebrity help to shape the kinds of feminisms that come to publicly circulate and that, to varying degrees, come to receive cultural legitimation, making the kind of conversation initiated through this Forum both critically and politically imperative.

\section{References}

Adichie, C.N., 2014. We should all be feminists. London: Fourth Estate.

Gay, R., 2014. Emma Watson? Jennifer Lawrence? These aren't the feminists you're 
looking for, The Guardian, 10 October. Available from http://www.theguardian.com/commentisfree/2014/oct/10/-sp-jenniferlawrence-emma-watson-feminists-celebrity [Accessed 24 October 2014].

Kashner, S., 2014. Both huntress and prey, Vanity Fair, November, 130-137, 183.

Little, A., 2014. We spleen: TIME's “feminist” hate-fest, Ms. Magazine blog, 12 November. Available from http://msmagazine.com/blog/2014/11/12/wespleen-times-feminist-hate-fest/ [Accessed 19 November 2014].

Merlan, K., 2014. 4Chan is why 'feminist' is winning the TIME poll of words to ban, Jezebel, 12 November. Available from http://jezebel.com/4chan-is-whyfeminist-is-winning-the-time-poll-of-words-1657927072 [Accessed 19 November 2014].

O'Connor, R., 2014. Dear TIME magazine, you can stop using the word 'feminist' when women no longer need feminism, The Independent, 13 November. Available from http://www.independent.co.uk/voices/comment/dear-timemagazine-well-stop-using-the-word-feminist-when-women-no-longer-needfeminism-9859267.html [Accessed 19 November 2014]

Projansky, S., 2014. Spectacular girls: Media fascination and celebrity culture. New York: New York University Press.

Senft, T., 2008. Camgirls: Celebrity and community in the age of social networks. New York: Peter Lang.

Steinmetz, K., 2014. Which word should be banned in 2015? Time, 12 November. Available from http://time.com/3576870/worst-words-poll-2014/ [Accessed 19 November 2014].

Taylor, A., 2008. Mediating Australian feminism. Oxford: Peter Lang. 2014. 'Blockbuster' celebrity feminism. Celebrity studies, 5 (1-2), 75-78. 
(forthcoming) Celebrity and the feminist blockbuster. Basingstoke: Palgrave Macmillan.

Wicke, J., 1994. Celebrity feminism: materialist feminism and the culture of celebrity. South Atlantic quarterly, 93 (4), 751-778. 